Fish \& Shellfish Immunology

August 2015, Volume 45, Issue 2, Pages 933-939

http://dx.doi.org/10.1016/i.fsi.2015.05.041

http://archimer.ifremer.fr/doc/00270/38116/

(c) 2015 Elsevier Ltd. All rights reserved.

\title{
Rearing effect of biofloc on antioxidant and antimicrobial transcriptional response in Litopenaeus stylirostris shrimp facing an experimental sub-lethal hydrogen peroxide stress
}

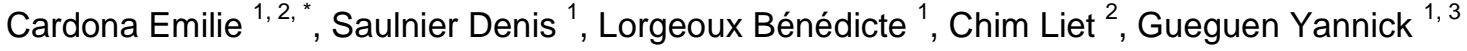

${ }^{1}$ Ifremer, Centre Océanologique du Pacifique, Unité de recherche Resources Marines, B.P 7004, 98719

Taravao, French Polynesia

${ }^{2}$ Ifremer, Unité de recherche Lagons, Ecosystèmes et Aquaculture Durable en Nouvelle Calédonie B.P. 2059, 98846 Nouméa, New Caledonia

${ }^{3}$ Ifremer, UMR 5244 IHPE, UPVD, CNRS, Université de Montpellier, F-34095 Montpellier, France

* Corresponding author : Emilie Cardona, email address : emiliecardona2@gmail.com

\begin{abstract}
:
This study compares the antioxidant and antimicrobial transcriptional expression of blue shrimps reared according to two different systems, BioFloc Technology (BFT) and Clear sea Water (CW) and their differential responses when facing an experimental sublethal hydrogen peroxide stress. After 30 days of rearing, juvenile shrimps were exposed to $\mathrm{H} 2 \mathrm{O} 2$ stress at a concentration of $30 \mathrm{ppm}$ during 6 hours. The oxidative stress caused by $\mathrm{H} 2 \mathrm{O} 2$ was examined in the digestive glands of the shrimp, in which antioxidant enzyme (AOE) and antimicrobial peptide (AMP) gene expression were analysed by quantitative real-time PCR. Results showed that rearing conditions did not affect the expression of genes encoding AOEs or AMPs. However, $\mathrm{H}_{2} \mathrm{O} 2$ stress induced a differential response in expression between shrimps from the two rearing treatments (BFT and $\mathrm{CW}$ ). Comparative analysis of the expression profiles indicates that catalase transcripts were significantly upregulated by $\mathrm{H} 2 \mathrm{O} 2$ stress for BFT shrimps while no change was observed for CW shrimps. In contrast, $\mathrm{H} 2 \mathrm{O} 2$ caused downregulation of superoxide dismutase and glutathione transferase transcripts and of the three AMP transcripts studied (penaeidin 2 and 3 , and crustin) for CW shrimps, while no effect was observed on BFT shrimp transcript levels. These results suggested that BFT shrimps maintained antioxidant and AMP responses after stress and therefore can effectively protect their cells against oxidative stress, while CW shrimp immune competence seems to decrease after stress.
\end{abstract}

\section{Highlights}

- Contrasted rearing conditions, biofloc and clear water, did not affect the expression of genes encoding antioxidant enzymes and antimicrobial peptides. Biofloc shrimps maintained antioxidant and antimicrobial peptide responses after $\mathrm{H}_{2} \mathrm{O}_{2}$ stress while the immune competence of clear water shrimp seemed to decrease after stress. Biofloc seems to improve the immune resistance of animals against stress. 
Keywords : biofloc, shrimps, antimicrobial peptides, antioxidant enzymes

\section{Introduction}

In shrimp aquaculture, intense interest has focused on biofloc technology (BFT). BFT is a rearing system with zero or minimal water exchange. Conglomerates of microbes, algae, protozoa and other organisms, together with detritus and dead organic particles, develop in the water column (Avnimelech, 2009). The intensive microbial community present in this system can be used as a water quality treatment system for the pond and microbial protein can serve as a feed additive. At the present time, when shrimp production faces many losses due to disease outbreaks, the use of BFT can restrain the development of shrimp diseases. One explanation is that, with zero or minimal water exchange, BFT improves biosecurity because the exclusion of pathogens is enhanced by limiting contact with water from external aquatic ecosystems (Taw, 2013). Another explanation is that the microbial proteins assimilated by shrimp are believed to confer beneficial effects on well-being and shrimp immune status (Avnimelech, 2009). Nevertheless, the influence of biofloc on shrimp immune status has been poorly

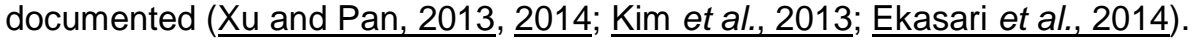

Because of their lack of acquired immunity, marine invertebrates' defence against invading pathogens relies solely on innate immune mechanisms (Mitta et al., 2000). In shrimp these include: 1) pattern recognition receptors (PRR) (Wang and Wang, 2013); 2) humeral 
responses characterized by the expression of antimicrobial peptides (AMPs), (Destoumieux et al., 1997) but also coagulation and melanisation by so-called clotting (Omori et al., 1989; Yeh et al., 1998; Chen et al., 2005) and prophenoloxidase activating systems (Sritunyalucksana and Söderhäll, 2000; Lee et al., 2002; Charoensapsri et al., 2011); 3) cellular responses, mainly performed by haemocytes, such as phagocytosis (Song et al., 1994), chemotaxis with haemocyte migration into inflammatory foci (Munoz et al., 2002), release of humeral defence components (agglutinins, coagulation and phenoloxidase enzymes, antimicrobial peptides), encapsulation and nodule formation (Holmblad and Söderhäll, 1999).

Animal stress induced by sub-lethal $\mathrm{H}_{2} \mathrm{O}_{2}$ concentration is a method rarely used to induce stress and therefore original. It seemed interesting to study the response of animals to $\mathrm{H}_{2} \mathrm{O}_{2}$ stress because, although oxygen radical stress and antioxidant protection are coming increasingly into focus in physiological research on marine invertebrates, only a few studies have considered the effects of elevated concentrations of reactive oxygen species (ROS) on invertebrate physiology (Abele-Oeschger et al., 1997). Among commonly used biomarkers of immunity, antioxidant enzymes (AOEs) are directly involved in scavenging ROS and play pivotal roles in preventing damage generated by oxidative stress. ROS have been identified as major initiators of tissue damage and can upregulate enzyme activity, signal transcription, and gene expression (Massafra et al., 2000). The antioxidant defence and immune systems are closely linked to responses to pathogens and other stress-related issues that might lead to respiratory burst (Holmblad and Söderhäll, 1999). Measuring AOE expression after environmental stressors such as $\mathrm{pH}$ (Wang et al., 2009), temperature, salinity, hypoxia (De Zoysa et al., 2009) and $\mathrm{H}_{2} \mathrm{O}_{2}$ stress (De Zoysa et al., 2008) has proven to be a very good tool to study the responses of aquatic invertebrates. In contrast, very few studies have used antimicrobial peptide (AMP) analysis to investigate the impact of environmental stress on invertebrate immunology (Mitta et al., 2000, Cellura et al., 2007; Li et al., 2009). The major studies on AMPs have focused on their identification, characterization, and regulation following pathogen infection (Bachère et al., 2004). However, investigating AMPs can provide a unique opportunity to greatly advance current understanding in the field of ecological immunology and especially the impact of environmental stressors (Ellis et al., 2011).

In our study, we explore the transcriptional responses of genes coding either for AOEs or AMPs in shrimp during contrasted rearing conditions, biofloc versus clear seawater, and experimentally induced stress produced by a sub-lethal dose of hydrogen peroxide. 
Materials and method

97

\section{Shrimps}

The 12 day-old shrimps post-larvae Litopenaeus stylirostris used in this experiment were supplied by the hatchery of the Aquaculture Technical Centre of Tahiti (French Polynesia). Shrimps acclimated during 15 days in a $25 \mathrm{~m}^{3}$ clear seawater tank (300\% water renewal per day) and were fed three times per day with commercial feed at $20 \%$ of the shrimp biomass (SICA grower 40).

\section{Biofloc production}

The biofloc culture was established before the experiment in 4 tanks (250 L) with sub-adult shrimps (mean weight: 20 g, biomass: 500 g.m²) and fed twice per day with commercial shrimp feed (SICA grower 40) during 30 days. The shrimps were removed before the beginning of the experiment. Aeration was delivered continuously via an air stone in each tank. No water exchange was performed. Tanks were covered with a shade net to control the sunlight (70\% inhibition of light).

\section{Experimental design}

Shrimps were caught in clear water tanks using a cast net and randomly distributed into 8 tanks $(250 \mathrm{~L})$. One hundred individuals $(0.07 \pm 0.02 \mathrm{~g})$ were put into each tank (400 shrimps. $\mathrm{m}^{-2}$ ). Each tank was continuously aerated with an air stone. No water was exchanged during the experimental period in the biofloc rearing system and a water renewal rate of $300 \%$ per day was applied in the clear seawater rearing system.

Two treatments with four replicate tanks for a period of 30 days were tested: clear seawater (CW) and biofloc (BFT). Shrimps were fed ad libitum 3 times per day (07:00 am, 01:00 pm and 05:00 pm) with commercial shrimp feed (SICA® grower 40). The pellet given to shrimp was the only source of carbon. It is equivalent to a $\mathrm{C} / \mathrm{N}$ ratio of $8 / 1$.

\section{$\mathrm{H}_{2} \mathrm{O}_{2}$ stress, sampling and conservation}

To achieve $\mathrm{H}_{2} \mathrm{O}_{2}$ stress, water renewal was operated in the biofloc tank during 12 hours to place the shrimp in sea clear water. During stress, all shrimps were maintained under the same conditions (clear seawater, temperature $=26.3^{\circ} \mathrm{C}$, salinity $=34.5 \%$ o, $\mathrm{pH}=8.20$ ). 
Then, all shrimps remaining in the tanks were stressed by immersion for 6 hours with a sublethal concentration of $\mathrm{H}_{2} \mathrm{O}_{2}(30 \mathrm{ppm})$ added directly to the rearing tank.

Only shrimps in the inter-molt phase were sampled for molecular analysis. Molting stages were determined by microscopic examination of antennal scales according to the method of Drach and Tchernigovtzeff (1967). This was to minimize variations, because changes in physiological parameters are generally observed during the molting cycle in crustaceans.

The sampling was performed before and after 6 hours of stress; ten shrimps per tank were caught and put directly in iced seawater $\left(0^{\circ} \mathrm{C}\right)$. Because of their small size, only digestive gland tissues were sampled.

The digestive glands of 10 intermolt shrimps per tank (before and after $\mathrm{H}_{2} \mathrm{O}_{2}$ stress) were removed. The tissues were immediately pooled in RNA Later $\left(\operatorname{Sigma}{ }^{\circledR}\right)$, refrigerated at $4{ }^{\circ} \mathrm{C}$ for 12 hours and kept at $-80{ }^{\circ} \mathrm{C}$ until analysis.

Antioxidant and AMP gene expression analysis by relative quantitative real-time PCR (q-PCR)

Total RNA from the digestive glands was extracted using the Trizol method (Invitrogen, USA) according to the manufacturer's instructions. The quantity and quality of each RNA were assessed by measuring their absorbance at 260 and $280 \mathrm{~nm}$ using a Nanodrop 1000 Spectrophotometer (Thermo Scientific) associated with ND-1000 V3 7.0 software. A DNAse treatment to remove residual DNA was carried out using the Ambion DNAse free kit, following the manufacturer's instructions.

First-strand cDNA was synthesized with 500 ng of total RNA in each reaction system using the Roche ${ }^{\odot}$ transcriptor first strand cDNA synthesis system according to the manufacturer's protocol. All cDNAs were diluted 1/100 with nuclease-free water and stored at $-20{ }^{\circ} \mathrm{C}$ until used as templates in real-time quantitative PCR (qRT-PCR).

Specific primers for Catalase (CAT), Glutathione peroxidase (GPX), Super oxide dismutase (SOD), and glutathione transferase (GSHT) were obtained by alignment of the most conserved regions from those sequences registered in Genbank. Primers for AMP genes, lysozyme (Lyso), Peneaidin 2 and 3 (Pen 2, Pen 3) and Crustin (Cru) were obtained from De Lorgeril et al. (2008). The primer sequences are shown in table 1. 
Real-time qRT-PCR was carried out in a Stratagene Mx3000P machine (Agilent Technologies) using Brilliant® II SYBR® Green QPCR Master Mix following the manufacturer's recommendations. The reactions were mixed in a volume of $25 \mu \mathrm{L}$ containing 12.5 $\mu \mathrm{L}$ SYBR Premix, $10 \mu \mathrm{L}$ cDNA (diluted 1/100), and $1.25 \mu \mathrm{L}$ each of the $4 \mu \mathrm{M}$ forward and reverse primers. After initial denaturation at $95^{\circ} \mathrm{C}$ for $10 \mathrm{~min}, 40$ cycles of amplification were carried out starting at $95{ }^{\circ} \mathrm{C}$ for $30 \mathrm{~s}$, followed by $45 \mathrm{~s}$ at $57{ }^{\circ} \mathrm{C}$ and $45 \mathrm{~s}$ at $72{ }^{\circ} \mathrm{C}$, with a final extension at $95^{\circ} \mathrm{C}$ for $1 \mathrm{~min}, 30 \mathrm{sec}$ at $55^{\circ} \mathrm{C}$ and at $95^{\circ} \mathrm{C}$ for $30 \mathrm{sec}$ followed by a final cycle for differentiation curve analysis.

To determine the RT-PCR efficiencies of each primer pair used, standard curves were generated using five serial dilutions (one log of dilution) of a pool of one hundred cDNA samples from the hepatopancreas. The primers' ability was validated when the amplification efficiency varied between 90 and 110\%.

Then, all samples collected during the experiment were run in duplicate. Relative gene expression levels were normalized against two specific house-keeping genes, Elongation factor (EF) and glyceraldehyde-3-phosphate-deshydrogenase (GADPH), and each value was calculated in reference to $\mathrm{CW}$ shrimps before stress (relative expression $=1$ ) according to the $2^{-\Delta \Delta \mathrm{Ct}}$ method (Livak and Schmittgen, 2001).

\section{Statistical analysis}

Statistical analysis of the data was carried out using XLSTAT software 2012. Percent data (survival rate) were normalized using an arcsine transformation before analysis. The normality of the data distribution and homogeneity of variance were tested for all zootechnical and molecular analysis data using the Shapiro-Wilk test and F-test, respectively. The zootechnical data were normally distributed and variances were homogenous. Hence, the effects of the rearing treatments were tested using a one-way analysis of variance. The molecular results were not normally distributed; the effects of the rearing treatments were tested using the Kruskal-Wallis test.

\section{Results}

\section{Survival and growth}

After 30 days of rearing, BFT shrimp presented a significantly higher survival rate compared to CW shrimp $(99.30 \pm 1.30 \%$ vs. $42.17 \pm 15.35 \%, \mathrm{p}<0.01)$. The mean body weight of the 
BFT shrimp at the end of rearing $(0.88 \pm 0.19 \mathrm{~g})$ was significantly higher than in the CW treatment $(0.21 \pm 0.04 \mathrm{~g})(\mathrm{p}=0.001)$.

\section{Expression profiling of antioxidant enzyme genes}

For all genes studied, the rearing period did not induce a difference of expression between the two conditions. However, $\mathrm{H}_{2} \mathrm{O}_{2}$ stress did cause different patterns of expression between the two conditions (Figure 1). As a reminder, relative gene expression levels were normalized with two specific housekeeping genes, Elongation factor (EF) and glyceraldehyde-3phosphate-dehydrogenase (GADPH), and each value was calculated in reference to $\mathrm{CW}$ shrimps before stress. SOD and GSHT for CW shrimps showed a significantly decreased relative transcript abundance 6 hours after stress, $0.39 \pm 0.03$ and $0.31 \pm 0.12$, respectively ( $p=0.03$ for both genes), while no significant change was observed for BFT shrimps $(0.84 \pm$ 0.26 and $0.97 \pm 0.65, p>0.05)$. The difference between BFT and CW shrimps after stress was significantly different for SOD and GSHT ( $p<0.01$ and $p=0.04$, respectively). Nevertheless, no effect of stress was observed on GPX expression for animals under either condition. CAT showed a distinct pattern compared to other antioxidant enzymes. BFT shrimps displayed a significant increase in relative RNA abundance after stress $(p=0.04)$ compared to $\mathrm{CW}$ shrimps, in which the relative abundance of CAT RNA did not change $(2.39 \pm 1.49$ vs. $0.76 \pm$ $0.28, p=0.02)$.

\section{Expression profiling of antimicrobial peptide genes}

As for antioxidant enzyme genes, for all AMPs genes studied, the rearing period did not induce differences in expression between the two conditions. However, $\mathrm{H}_{2} \mathrm{O}_{2}$ stress caused different patterns of expression under both conditions (Figure 2). For the penaeidin family, the relative transcript abundance of Pen 2 and Pen 3 decreased significantly after stress in CW shrimps ( $p=0.03$ for both genes). On the contrary, in the BFT shrimps, no change in Pen 2 and Pen 3 transcript abundance was detected after stress compared to before stress ( $>0.05)$. However, significant differences were observed between rearing conditions after stress; respectively, for CW and BFT, $0.15 \pm 0.08 v s .0 .94 \pm 0.40(p=0.03)$ for Pen 2 and $0.14 \pm 0.06$ vs. $0.88 \pm 0.53(p=0.02)$ for Pen 3. Similar to the penaeidin family, another AMP (Cru) transcript showed a significant decrease in RNA abundance 6 hours after stress in CW shrimps, $(0.12 \pm 0.04, p=0.03)$, but not in BFT shrimps $(0.41 \pm 0.23, p>0.05)$. The difference 
between BFT and CW shrimps was significant $(p=0.03)$. No effect of induced stress was observed on lysozyme expression in animals from the two conditions.

\section{Discussion}

At the present time, when shrimp production faces many losses due to disease outbreaks, the use of BFT can restrain the development of shrimp diseases. It has been hypothesized that the biofloc allowed the shrimp to better withstand environmental stress or infection by pathogenic bacteria or viruses by stimulating non-specific immunity. Recently, several authors determined that BFT stimulated the non-specific immunity of shrimp (Kim et al., 2013; Xu and Pan, 2013, 2014; Ekasari et al., 2014) and one recent work showed that BFT improved shrimp resistance to infectious myonecrosis virus infection (Ekasari et al., 2014). In this research, the antioxidant and antimicrobial transcriptional responses before and after experimental sub-lethal hydrogen peroxide stress in blue shrimps reared according to two different systems, BFT and CW, were compared in order to improve our understanding of BFT's action on antioxidant defences and the humeral immune system of shrimps at the transcriptional level. We undertook, for the first time, to monitor AOE and AMP gene expression in shrimps under different rearing conditions, BFT and CW, and after induced stress.

\section{Biofloc rearing conditions improves shrimp growth and survival}

Our results showed that the BFT system promotes better growth (x 4.2) and survival (x 0.4) of Litopenaeus stylirostris juvenile shrimps compared to the CW system. Such results have already been described (Moss and Pruder, 1995; Cohen et al., 2005; Azim and Little, 2008; Mishra et al., 2008). According to these authors, the improved performances can be related to the consumption of biofloc by the shrimp, as a source of bacteria, microalgae and zooplankton, which could enhance shrimp nutrition and immunity. In the biofloc system, its natural productivity plays an important and complementary nutritional role for the shrimp in addition to the artificial pellets (Moss and Pruder 1995; Epp et al., 2002; Tacon et al., 2002; Burford et al., 2004). Biofloc is known to be an important source of proteins (Wasielesky et al., 2006) and also of lipids (Crab et al., 2010). Moreover, biofloc can contain microbially bioactive components such as carotenoids, vitamins (Ju et al., 2008) and glutathione (Cardona et al., in prep.). Major nutrients like proteins, lipids, antioxidant and vitamins, carotenoids and 
minerals are known to participate, in different ways, in nutritional modulation of immune responses (Trichet, 2010).

\section{Shrimp AOE and AMP gene expression are not modified by rearing conditions}

However, in the absence of any particular stressful conditions, we showed that the transcriptional responses of AOE and AMP genes of shrimp were not different between the different rearing conditions. With the significantly different growth and survival results obtained, we could expect a differential response between animals from the two conditions, as shown by others authors. Indeed, Kim et al. (2013) showed that biofloc rearing improved immune-related gene expression in L.vannamei post-larvae. Nevertheless, these authors used different biomarkers of shrimp immunity than those used in this study. Indeed, the genes targeted were involved in prophenoloxidase (ProPo) cascade activation (6 studied genes: prophenoloxidase 1, prophenoloxidase 2, prophenoloxidase activating enzyme, serine protease, and masquerade-like serine protease). The ProPo cascade can be activated by components of the cell wall like $\beta$-1,3-glucan, lipopolysaccharide, and peptidoglycan, elicitors found abundantly on biofloc particles (Johansson \& Söderhäll, 1985; Van de Braak et al., 2002; Amparyup et al., 2013). Indeed, bacteria were one of the principal constituents identified in biofloc particles, with a high concentration ranging from $10^{6}$ to $10^{9}$ cell. $\mathrm{mL}^{-1}$ (Otoshi et al., 2006; Burford et al., 2003; Avnimelech, 2009; Kim et al., 2013).

Moreover, in addition to activating the ProPo cascade, earlier studies have revealed that biofloc led to an increase in both total haemocyte count and the phagocytic response in shrimp hemolymph, whereas respiratory burst, antibacterial and bacteriolytic activities were not affected (Xu and Pan, 2013; Ekasari et al., 2014). The presence and digestion of the biofloc ingested by the shrimp may release substances in the gastrointestinal tract that could potentially stimulate cellular defences (phagocytosis and the proPo cascade) and the release of more haemocytes into the circulation without a noticeable effect on humeral defence factor (such as AMPs and lysozyme) production (Xu and Pan, 2013). Our results are in accordance with these assertions and confirm that at the gene expression level there is no effect of the BFT condition by comparison to $\mathrm{CW}$.

Differential AOE and AMP responses induced by $\mathrm{H}_{2} \mathrm{O}_{2}$ stress between shrimps from BFT and CW 
After a $\mathrm{H}_{2} \mathrm{O}_{2}$ stress treatment, a strong effect of the rearing condition was noticed in $\mathrm{AOE}$ and AMP gene expression levels. The antioxidant defence system is inducible at a moderately high concentration of $\mathrm{H}_{2} \mathrm{O}_{2}$, which is hypothesized to also act as a messenger of signal transduction by regulating the mRNA level through activation of signal pathways (Ji, 1995; Sen and Packer, 1996). In this study, the expression of CAT was significantly increased in the digestive gland after 6 hours under $\mathrm{H}_{2} \mathrm{O}_{2}$ exposure for animals reared in BFT, while no change in RNA transcript abundance was recorded for CW shrimps. This result suggested that $\mathrm{H}_{2} \mathrm{O}_{2}$ stimulated the expression of CAT in BFT animals. AOEs' function is to catalyse the conversion of $\mathrm{H}_{2} \mathrm{O}_{2}$ into water and molecular $\mathrm{O}_{2}$ to protect the organism from peroxidation (Zhang et al., 2008). This result seems to show that excess $\mathrm{H}_{2} \mathrm{O}_{2}$ that penetrates cells and tissues would be more easily detoxified and neutralized in the cytosol by catalase in BFT shrimp than in CW shrimp. The increase in CAT RNA expression in BFT shrimp could correspond to an adaptive antioxidant stress response (Bigot et al., 2010). In contrast, the absence of a response in the $\mathrm{CW}$ shrimps could reflect an inappropriate response of the organism to neutralize peroxides and their potential involvement in oxidative cellular damage (Meng et al., 2014). GPX also catalyses the conversion of $\mathrm{H}_{2} \mathrm{O}_{2}$ into $\mathrm{H}_{2} \mathrm{O}$ and $\mathrm{O}_{2}$. The absence of significant differential expression before and after 6 hours under stress could be explained by it being too short a time for the animals to react or to the paucity of biological replicates $(n=4)$ to draw out significant differences. Indeed, Fu et al. (2012) showed that GPX mRNA transcription increased significantly between $8 \mathrm{~h}$ and $12 \mathrm{~h}$ after $\mathrm{H}_{2} \mathrm{O}_{2}$ injection. Stress induced significant down-regulation of SOD and GSHT in CW animals only. Similar to our findings on CAT genes, this could be explained by a diminished capacity for the $\mathrm{CW}$ organism to protect itself against oxidative stress (Bigot et al., 2010) and the degradation of cells by $\mathrm{H}_{2} \mathrm{O}_{2}$. All together, the difference in response between animals from the two rearing conditions suggests that $\mathrm{CW}$ shrimp did not seem able to abolish cytotoxic effects due to $\mathrm{H}_{2} \mathrm{O}_{2}$-induced oxidative stress, while BFT shrimp seemed to present an adaptive antioxidant stress response. For information, we had measured SOD and CAT enzymatic activities. However, the observed standard deviations of the results were very important. Thus, it was very difficult to define correlations with the molecular data. These observations could be explained by the fact that it is not so easy to measure and interpret enzymatic activities on crude extract. Many activity inhibitors could be present in the extract. Therefore, we have decided not to show these biochemical results. 
In addition to AOE production, haemocytes are able to synthesize soluble antimicrobial peptides (AMPs). Measuring humeral immunity offers a further insight into the impact of stressors on haemocyte functionality, associated with an organism's immunocompetence (Ellis et al., 2011). This study shows differences in AMP gene expression levels according to the rearing conditions of $L$. stylirostris facing a $\mathrm{H}_{2} \mathrm{O}_{2}$ stress. The transcript levels of three out of four AMP genes studied (Pen 2 and 3, Crustin) appeared to be significantly modified after stress in CW shrimps only. The reported modulations in mRNA quantities were distributed in circulating haemocytes present in the digestive gland, since in invertebrates AMPs are produced mostly by haemocytes (Bachère et al., 2004). In our experiment, no cell counts were performed before RNA extraction. Total RNA quantities were adjusted before reverse transcription and cDNA concentrations were adjusted another time in order to use identical template quantities in qPCR. Meanwhile, we have no data on the quantitative and qualitative composition of the various haemocytes sampled. The decreases in the AMP transcripts of CW shrimps could be explained by two phenomena: (i) a decrease in the relative number of haemocytes expressing the considered mRNA (Cellura et al., 2007) induced by $\mathrm{H}_{2} \mathrm{O}_{2}$ cytotoxicity and (ii) a migration of haemocytes from the digestive gland towards exposed tissue to $\mathrm{H}_{2} \mathrm{O}_{2}$ as is often observed after infection by a pathogen or by injury (Bachère et al., 2004). However, the observed differences in AMP transcript level could be compared to the data observed for shrimp survival under the BFT and CW conditions. We can suppose that the differential AMP transcriptional response after stress could be related to an improved immune ability of BFT animals facing a $\mathrm{H}_{2} \mathrm{O}_{2}$ stress. Nevertheless, further study is needed to confirm this assumption.

\section{Conclusion}

The rearing condition, BFT or $\mathrm{CW}$, did not affect gene expression encoding antioxidant enzymes and antimicrobial peptides, although BFT significantly improved the growth and survival of animals. However, $\mathrm{H}_{2} \mathrm{O}_{2}$ stress induced a differential response in AOEs and AMPs between shrimp from BFT and CW. Biofloc shrimps seem to maintain their antioxidant and antimicrobial peptide responses after $\mathrm{H}_{2} \mathrm{O}_{2}$ stress, while clear water shrimp immune competence seemed to decrease after stress.

\section{Acknowledgements}


This study was sponsored by the Government and Southern, Northern and Island Provinces of New-Caledonia and the management of marine resources and mining of Tahiti. We would like to thank the Technical Centre for Aquaculture of Tahiti for their help during the running of the experiment, Julie Fievet for help during the sampling and Julien De Lorgeril for the discussions on shrimp antimicrobial peptides.

\section{References}

Abele-Oeschger, D., Tüg, H., Roettgers, R., 1997. Dynamics of UV-driven hydrogen peroxide formation on an intertidal sandflat. Limnology and oceanography, 42(6), 1406-1415.

Abele, D., Burlando, B., Viarengo, A., Pörtner, H.O., 1998. Exposure to elevated temperatures and hydrogen peroxide elicits oxidative stress and antioxidant response in the Antarctic intertidal limpet Nacella concinna. Comparative Biochemistry and Physiology Part B: Biochemistry and Molecular Biology, 120(2), 425-435.

Abele, D., Puntarulo, S., 2004. Formation of reactive species and induction of antioxidant defence systems in polar and temperate marine invertebrates and fish. Comparative Biochemistry and Physiology Part A: Molecular \& Integrative Physiology, 138(4), 405415.

Amparyup, P., Charoensapsri, W., \& Tassanakajon, A., 2013. Prophenoloxidase system and its role in shrimp immune responses against major pathogens. Fish \& shellfish immunology, 34(4), 990-1001.

Avnimelech, Y., 2009. Biofloc Technology - A practical guide Book. Baton Rouge, Louisiana, United States, The World Aquaculture Society.

Azim M.E., Little D.C., Bron J.E., 2008. Microbial protein production in activated suspension tanks manipulating C:N ratio in feed and the implications for fish culture. Bioresource Technology, 99 (2008), pp 3590-3599.

Bachère, E., Gueguen, Y., Gonzalez, M., De Lorgeril, J., Garnier, J., Romestand, B., 2004. Insights into the anti-microbial defense of marine invertebrates: the penaeid shrimps and the oyster Crassostrea gigas. Immunological reviews, 198(1), 149-168.

Bartlett, T.C., Cuthbertson, B.J., Shepard, E.F., Chapman, R.W., Gross, P.S., Warr, G.W., 2002. Crustins, homologues of an 11.5-kDa antibacterial peptide, from two species of penaeid shrimp, Litopenaeus vannamei and Litopenaeus setiferus. Journal of Marine Biotechnology (NY) 4 (3): 278-293.

Becerra-Dorame, J.M., Martinez-Cordova, L. R., Martínez-Porchas, M., Hernández-López, J., López-Elías, J. A., \& Mendoza-Cano, F., 2012. Effect of using autotrophic and 
heterotrophic microbial-based-systems for the pre-grown of Litopenaeus vannamei, on the production performance and selected haemolymph parameters. Aquaculture Research.

Bigot, A., Vasseur, P., Rodius, F., 2010. SOD and CAT cDNA cloning, and expression pattern of detoxification genes in the freshwater bivalve Unio tumidus transplanted into the Moselle river. Ecotoxicology, 19(2), 369-376.

Burford M.A., Thompson P.J., Bauman H., Pearson D.C., 2003. Microbial communities affect water quality, shrimp performance at Belize Aquaculture. Global Aquaculture Advocate 6, 64-65.

Burford, M.A., Thompson, P.J., McIntosh, P.R., Bauman, R.H., Pearson, D.C., 2004. The contribution of flocculated material to shrimp (Litopenaeus vannamei) nutrition in a high-intensity, zero exchange system. Aquaculture 232, 525-537.

Cellura, C., Toubiana, M., Parrinello, N., Roch, P., 2007. Specific expression of antimicrobial peptide and HSP70 genes in response to heat-shock and several bacterial challenges in mussels. Fish \& shellfish immunology, 22(4), 340-350.

Chandra, J., Samali, A., Orrenius, S., 2000. Triggering and modulation of apoptosis by oxidative stress. Free Radical Biology and Medicine, 29(3), 323-333.

Charoensapsri, W., Amparyup, P., Hirono, I., Aoki, T., and Tassanakajon, A., 2011. Pm PPAE2, a new class of crustacean prophenoloxidase (proPO)-activating enzyme and its role in PO activation. Developmental \& Comparative Immunology, Vol. 35, No. 1, pp. 115-124.

Chen, M.Y., Hu, K.Y., Huang, C.C., Song, Y.L., 2005. More than one type of transglutaminase in invertebrates? A second type of transglutaminase is involved in shrimp coagulation. Developmental \& Comparative Immunology, Vol. 29, No. 12, pp. 1003-1016.

Cohen, J.M., Samocha, T.M., Fox, J.M., Gandy, R.L., Lawrence, A.L., 2005. Characterization of water quality factors during intensive raceway production of juvenile Litopenaeus vannamei using limited discharge and biosecure management tools. Aquacultural engineering, 32(3), 425-442.

Crab, R., Chielens, B., Wille, M., Bossier, P., Verstraete, W., 2010. The effect of different carbon sources on the nutritional value of bioflocs, a feed for Macrobrachium rosenbergii postlarvae. Aquaculture Research, 41(4), 559-567.

De la Vega, E., O’Leary, N. A., Shockey, J. E., Robalino, J., Payne, C., Browdy, C. L., ... \& Gross, P. S., 2008. Anti-lipopolysaccharide factor in Litopenaeus vannamei (LvALF): 
A broad spectrum antimicrobial peptide essential for shrimp immunity against bacterial and fungal infection. Molecular immunology, 45(7), 1916-1925.

De Lorgeril, J., Saulnier, D., Janech, M. G., Gueguen, Y., \& Bachere, E. (2005). Identification of genes that are differentially expressed in hemocytes of the Pacific blue shrimp (Litopenaeus stylirostris) surviving an infection with Vibrio penaeicida. Physiological genomics, 21(2), 174-183.

De Lorgeril, J., Gueguen, Y., Goarant, C., Goyard, E., Mugnier, C., Fievet, J., ... \& Bachère, E., 2008. A relationship between antimicrobial peptide gene expression and capacity of a selected shrimp line to survive a Vibrio infection. Molecular immunology, 45(12), 3438-3445.

Destoumieux, D., Bulet, P., Loew, D., Van Dorsselaer, A., Rodriguez, J., \& Bachère, E., 1997. Penaeidins, a new family of antimicrobial peptides isolated from the shrimp Penaeus vannamei (Decapoda). Journal of Biological Chemistry, 272(45), 2839828406.

De Zoysa, M., Pushpamali, W.A., Oh, C., Whang, I., Kim, S. J., Lee, J., 2008. Transcriptional up-regulation of disk abalone selenium dependent glutathione peroxidase by $\mathrm{H}_{2} \mathrm{O}_{2}$ oxidative stress and Vibrio alginolyticus bacterial infection. Fish \& shellfish immunology, 25(4), 446-457.

De Zoysa, M., Whang, I., Lee, Y., Lee, S., Lee, J. S., Lee, J., 2009. Transcriptional analysis of antioxidant and immune defense genes in disk abalone (Haliotis discus discus) during thermal, low-salinity and hypoxic stress. Comparative Biochemistry and Physiology Part B: Biochemistry and Molecular Biology, 154(4), 387-395.

Drach, P., Tchernifovtzeff, C., 1967. Sur la méthode de détermination des stades d'intermue et son application générale aux crustacés. Vie Milieu 18, 596-609.

Ellis, R.P., Parry, H., Spicer, J.I., Hutchinson, T.H., Pipe, R.K., Widdicombe, S., 2011. Immunological function in marine invertebrates: responses to environmental perturbation. Fish \& shellfish immunology, 30(6), 1209-1222.

Ekasari, J., Azhar, M. H., Surawidjaja, E. H., Nuryati, S., De Schryver, P., \& Bossier, P., 2014. Immune response and disease resistance of shrimp fed biofloc grown on different carbon sources. Fish \& shellfish immunology.

Epp, M.A., Ziemann, D.A., Schell, D.M., 2002. Carbon and nitrogen dynamics in zero-water exchange shrimp culture as indicated by stable isotope tracers. Aquaculture Research, 33(11), 839-846. 
Fu, M., Zou, Z., Liu, S., Lin, P., Wang, Y., Zhang, Z., 2012. Selenium-dependent glutathione peroxidase gene expression during gonad development and its response to LPS and $\mathrm{H}_{2} \mathrm{O}_{2}$ challenge in Scylla paramamosain. Fish \& shellfish immunology, 33(3), 532542.

Galloway, T.S., Depledge, M.H., 2001. Immunotoxicity in invertebrates: measurement and ecotoxicological relevance. Ecotoxicology, 10(1), 5-23.

Hikima, S., Hikima, J. I., Rojtinnakorn, J., Hirono, I., Aoki, T., 2003. Characterization and function of kuruma shrimp lysozyme possessing lytic activity against Vibrio species. Gene, 316, 187-195.

Holmblad, T., Söderhäll, K., 1999. Cell adhesion molecules and antioxidative enzymes in a crustacean, possible role in immunity. Aquaculture, 172(1), 111-123.

Ji, L.L., 1995. Exercise and free radical generation. Role of cellular antioxidant systems. Holoszy J. Exercise and Sports Science Review, Williams and Wilkins Co, Baltimore, Maryland, pp. 135-166.

Johansson, M. W., Söderhäll, K., 1985. Exocytosis of the prophenoloxidase activating system from crayfish haemocytes. Journal of Comparative Physiology B, 156(2), 175-181.

Ju Z., Forster I., Conquest L., Dominy W. 2008. Enhanced growth effects on shrimp (Litopenaeus vannamei) from inclusion of whole shrimp floc or floc fractions to a formulated diet. Aquaculture Nutrition 14.

Kim, S. K., Pang, Z., Seo, H. C., Cho, Y. R., Samocha, T., Jang, I. K., 2013. Effect of bioflocs on growth and immune activity of Pacific white shrimp, Litopenaeus vannamei postlarvae. Aquaculture Research, 45(2), 362-371.

Lee, K. Y., Zhang, R., Kim, M. S., Park, J. W., Park, H. Y., Kawabata, S.-i. and Lee, B. L., 2002. A zymogen form of masquerade-like serine proteinase homologue is cleaved during pro-phenoloxidase activation by $\mathrm{Ca} 2+$ in coleopteran and Tenebrio molitor larvae. European Journal of Biochemistry, 269: 4375-4383. doi: 10.1046/j.14321033.2002.03155.x

Le Moullac, G., Haffner, P., 2000. Environmental factors affecting immune responses in Crustacea. Aquaculture, 191(1), 121-131.

Li, H., Parisi, M.G., Toubiana, M., Cammarata, M., Roch, P., 2008. Lysozyme gene expression and hemocyte behaviour in the Mediterranean mussel, Mytilus galloprovincialis, after injection of various bacteria or temperature stresses. Fish \& shellfish immunology, 25(1), 143-152. 
Li, H., Toubiana, M., Monfort, P., Roch, P., 2009. Influence of temperature, salinity and E. coli tissue content on immune gene expression in mussel: Results from a 2005-2008 survey. Developmental \& Comparative Immunology, 33(9), 974-979.

Liu, K. F., Chiu, C. H., Shiu, Y. L., Cheng, W., Liu, C. H., 2010. Effects of the probiotic, Bacillus subtilis E20, on the survival, development, stress tolerance, and immune status of white shrimp, Litopenaeus vannamei larvae. Fish \& shellfish immunology, 28(5), 837-844.

Livak, K.J., Schmittgen, T. D., 2001. Analysis of Relative Gene Expression Data Using RealTime Quantitative PCR and the 2 $\Delta \Delta \mathrm{CTMethod.} \mathrm{Methods,} \mathrm{25(4),} \mathrm{402-408.}$

Livingstone, D.R., 2001. Contaminant-stimulated reactive oxygen species production and oxidative damage in aquatic organisms. Mar. Pollut. Bull. 42, 656-666.

Lushchak, V.I., 2011. Environmentally induced oxidative stress in aquatic animals. Aquatic Toxicology, 101(1), 13-30.

Massafra, C., Gioia, D., De Felice, C., Picciolini, E., De Leo, V., Bonifazi, M., Bernabei, A., 2000. Effects of estrogens and androgens on erythrocyte antioxidant superoxide dismutase, catalase and glutathione peroxidase activities during the menstrual cycle. Journal of endocrinology, 167(3), 447-452.

Meng, X.L., Liu, P., Li, J., Gao, B.Q., Chen, P., 2014. Physiological responses of swimming crab Portunus trituberculatus under cold acclimation: antioxidant defense and heat shock proteins. Aquaculture.

Mishra J.K., Samocha, T.M., Patnaik, S., Speed, M., Gandy, R.L., Ali, A., 2008. Performance of an intensive nursery system for the Pacific white shrimp, Litopenaeus vannamei, under limited discharge condition. Aquacultural Engineering38, 2-15.

Mitta, G., Hubert, F., Dyrynda, E.A., Boudry, P., Roch, P., 2000. Mytilin B and MGD2, two antimicrobial peptides of marine mussels: gene structure and expression analysis. Developmental \& Comparative Immunology, 24(4), 381-393.

Moss, S.M., Pruder, G.D., 1995. Characterization of organic particles associated with rapid growth in juvenile white shrimp, Penaeus vannamei Boone, reared under intensive culture conditions. Journal of Experimental Marine Biology and Ecology, 187(2), 175191.

Muñoz, M., Cedeño, R., Rodríguez, J., Van Der Knaap, W. P., Mialhe, E., Bachère, E., 2000. Measurement of reactive oxygen intermediate production in haemocytes of the penaeid shrimp, Penaeus vannamei. Aquaculture, 191(1), 89-107.0 
Muñoz, M., Vandenbulcke, F., Saulnier, D., Bachère, E., 2002. Expression and distribution of penaeidin antimicrobial peptides are regulated by haemocyte reactions in microbial challenged shrimp. European Journal of Biochemistry, 269(11), 2678-2689.

Omori, S.A., Martin, G.G., Hose, J.E., 1989. Morphology of hemocyte lysis and clotting in the ridgeback prawn, Sicyonia ingentis. Cell and Tissue Research, Vol. 255, No. 1, pp. 117-123.

Otoshi, C. A., Holl, C. M., Moss, D. R., Arce, S. M., Moss, S. M., 2006. Super-intensive RAS trial yields encouraging shrimp harvest at Oceanic Institute. Global Aquaculture Advocate, 9(4), 64-65.

Patil, P.K., Bhuvaneswari, T., Ezhil Praveena, P., Otta, S.K., 2014. Probiotics and immunostimulants in shrimp aquaculture. Pins Aquaculture- .training Manual on, 81.

Pallavi, P. N., Babu, K. N., Reddy, D. C., Kalarani, V., 2012. Antioxidant defenses and oxidative stress parameters in tissues of Penaeus monodon acclimated to different salinities. World, 4(5), 539-549.

Qiu, J., Wang, W.N., Wang, L.J., Liu Y.F., Wang A.L., 2011. Oxidative stress, DNA damage and osmolality in the Pacific white shrimp, Litopenaeus vannamei exposed to acute low temperature stress, Comparative Biochemistry and Physiology Part C: Toxicology \& Pharmacology, Volume 154, Issue 1, June 2011, Pages 36-41, ISSN 1532-0456, http://dx.doi.org/10.1016/j.cbpc.2011.02.007.

Rauen, U., Petrat, F., Li, T., De Groot, H., 2000. Hypothermia injury/cold-induced apoptosis-evidence of an increase in chelatable iron causing oxidative injury in spite of low O2-/H2O2 formation. The FASEB Journal, 14(13), 1953-1964.

Sen, C. K., Packer, L., 1996. Antioxidant and redox regulation of gene transcription. The FASEB journal, 10(7), 709-720.

Song, Y.L., Hsieh, Y.T., 1994. Immunostimulation of tiger shrimp (Penaeus monodon) hemocytes for generation of microbicidal substances: Analysis of reactive oxygen species. Developmental \& Comparative Immunology, 18(3), 201-209.

Song, Y.L., Li, C.Y., 2014. Shrimp immune system-special focus on penaeidin. Journal of Marine Science and Technology, 22(1), 1-8.

Sotelo-Mundo, R. R., Islas-Osuna, M. A., de-la-Re-Vega, E., Hernández-López, J., VargasAlbores, F., Yepiz-Plascencia, G., 2003. cDNA cloning of the lysozyme of the white shrimp Penaeus vannamei. Fish \& shellfish immunology, 15(4), 325-331.

Sritunyalucksana, K., Söderhäll, K., 2000. The proPO and clotting system in crustaceans. Aquaculture, 191(1), 53-69. 
Trichet, V.V., 2010. Nutrition and immunity: an update. Aquaculture Research, 41(3), 356372.

Van de Braak, C. B. T., Botterblom, M. H. A., Taverne, N., Van Muiswinkel, W. B., Rombout, J. H. W. M., Van der Knaap, W. P. W., 2002. The roles of haemocytes and the lymphoid organ in the clearance of injected Vibrio bacteria in Penaeus monodon shrimp. Fish \& shellfish immunology, 13(4), 293-309.

Victor, B., Narayanan, M., Jones Nelson, D., 1990. Gill pathology and hemocyte response in mercury exposed Macrobrachium idea (Heller). Journal of Environmental Biology, 11(1), 61-65.

Tacon, A.G.J., Cody, J., Conquest, L., Divakaran, S., Forster, I.P., Decamp, O., 2002. Effect of culture system on the nutrition and growth performance of Pacific white shrimp Litopenaeus vannamei (Boone) fed different diets. Aquaculture Nutrition 8, 121-137.

Taw, 2013. Shrimp farming : biofloc as biosecurity?. Book of abstract of Biofloc technology and shrimp disease workshop. World Aquaculture society HoChiMinh.

Wang, Y. C., Chang, P. S., Chen, H. Y., 2007. Tissue expressions of nine genes important to immune defence of the Pacific white shrimp Litopenaeus vannamei. Fish \& shellfish immunology, 23(6), 1161-1177.

Wang, W.N., Zhou, J., Wang, P., Tian, T.T., Zheng, Y., Liu, Y., Wei.Jun, M., Wang, A.L., 2009. Oxidative stress, DNA damage and antioxidant enzyme gene expression in the Pacific white shrimp, Litopenaeus vannamei when exposed to acute $\mathrm{pH}$ stress. Comparative Biochemistry and Physiology Part C: Toxicology \& Pharmacology, 150(4), 428-435.

Wang, D., Li, F., Chi, Y., Xiang, J., 2012. Potential relationship among three antioxidant enzymes in eliminating hydrogen peroxide in penaeid shrimp. Cell Stress and Chaperones, 17(4), 423-433.

Wang, X. W., \& Wang, J. X., 2013. Pattern recognition receptors acting in innate immune system of shrimp against pathogen infections. Fish \& shellfish immunology, 34(4), 981-989.

Wasielesky, W., Atwood, H., Stokes, A. Browdy, C.L., 2006. Effect of natural production in a zero exchange suspended microbial floc based super-intensive culture system for white shrimp Litopenaeus vannamei. Aquaculture 258, 396-403.

$\mathrm{Xu}$, W.J., Pan, L.Q., 2013. Enhancement of immune response and antioxidant status of Litopenaeus vannamei juvenile in biofloc-based culture tanks manipulating high $\mathrm{C} / \mathrm{N}$ ratio of feed input. Aquaculture, 412, 117-124. 
570

571

572

573

574

575

576

577

578

579

580

581

582

Xu, W.J., Pan, L.Q., 2014. Evaluation of dietary protein level on selected parameters of immune and antioxidant systems, and growth performance of juvenile Litopenaeus vannamei reared in zero-water exchange biofloc-based culture tanks. Aquaculture, 426, 181-188.

Yeh, M. S., Chen, Y. L., Tsai, I. H., 1998. The hemolymph clottable proteins of tiger shrimp, Penaeus monodon, and related species. Comparative Biochemistry and Physiology Part B: Biochemistry and Molecular Biology, Vol. 121, No. 2, pp. 169-176.

Zhang, Q., Li, F., Zhang, X., Dong, B., Zhang, J., Xie, Y., Xiang, J., 2008. cDNA cloning, characterization and expression analysis of the antioxidant enzyme gene, catalase, of Chinese shrimp Fenneropenaeus chinensis. Fish \& shellfish immunology, 24(5), 584591. 
Tables and captions

Table 1. PCR primers (F: Forward, R: Reverse) used to amplify antimicrobial peptides (Pen3, Pen2, Lyso, Cru), antioxidant enzymes (GPX, SOD, GSHT, CAT) and house-keeping genes (GADPH, EF) of the shrimp Litopenaeus stylirostris in a real-time PCR procedure.

Figure 1. Expression profiles of genes coding for the antioxidant enzymes Super oxide dismutase (SOD), Catalase (CAT), Glutathione peroxidase (GPX) and Glutathione transferase (GSHT) in animals under both conditions both before (BS) and after stress (AS).

Figure 2. Expression profiles of genes coding for AMPs, Lysozyme (Lyso), Peneaidin 2 and 3 (Pen 2 and Pen 3 ) and Crustin (Cru) in animals from both conditions both before (BS) and after stress (AS). 


\begin{tabular}{|c|c|c|c|c|c|c|}
\hline Name & Gene name & Sequence $5^{\prime}-3^{\prime \prime} 11$ VOURIP 1 & Size & Primer size & $\mathrm{Tm}$ & GeneBank \\
\hline Pen $2-\mathrm{F}$ & Peneaidin 2 & GTCTGCCTGGTCTTCTTGG & $178 \mathrm{pb}$ & 19 & 60 & AY351655 \\
\hline Pen 2 - R & Peneaidin 2 & CGAACCTGCTGCAGCAATTG & & 20 & 62 & \\
\hline Pen $3-\mathrm{F}$ & Peneaidin 3 & CCATGCGCCTCGTGGTCTG & $211 \mathrm{pb}$ & 19 & 64 & AY351656 \\
\hline Pen 3 - R & Peneaidin 3 & GAACGCGCTTGTAAGGTGGTAA & & 22 & 64 & \\
\hline Lyso - F & Lysozyme & GGCTTGGCACCAGGGTTACC & & 20 & 59 & CV699332 \\
\hline Lyso - R & Lysozyme & CGTCTGCACGTCAGCTGTG & & 20 & 59 & \\
\hline Cru - R & Crustin & GTGATTCTGTGCGGCCTCTT & $395 \mathrm{pb}$ & 30 & 63 & \\
\hline $\mathrm{Cru}-\mathrm{F}$ & Crustin & TCTTGCACCAATACCTGCAG & & 30 & 60 & \\
\hline GPX - F & Glutathione peroxidase & TCAACAGCTGATCCCGTCT & $157 \mathrm{pb}$ & 19 & 59 & \\
\hline GPX -R & Glutathione peroxidase & CCTTGCCGATGAGGAATTT & & 19 & 60 & \\
\hline SOD - F & Super oxide dismutase & GCAATGAATGCCCTTCTACC & $247 \mathrm{pb}$ & 20 & 60 & \\
\hline SOD - R & Super oxide dismutase & CAGAGCCTTTCACTCCAACG & & 21 & 60 & \\
\hline GSHT - F & Glutathione transferase & CTGGAGAAGCTGCACGAAG & $198 \mathrm{pb}$ & 19 & 60 & \\
\hline GSHT - R & Glutathione transferase & GTCACGTTCCTGTGCTTGC & & 19 & 60 & \\
\hline CAT - F & Catalase & TACTGCAAGTTCCATTACAAGACG & $285 \mathrm{pb}$ & 24 & 61 & \\
\hline CAT - R & Catalase & GTAATTCTTTGGATTGCGGTCA & & 22 & 61 & \\
\hline $\mathrm{EF}-\mathrm{F}$ & Elongation factor $1 \alpha$ & CGTTCCGGTGATCATGTTCTTGATG & $382 \mathrm{pb}$ & 35 & 60 & AY117542 \\
\hline EF - R & Elongation factor $1 \alpha$ & GGTGCTGGACAAGCTGAAGGC & & 31 & 60 & \\
\hline GADPH - F & Glyceraldehyde-3-phosphate-deshydrogenase & CGTTGGACACCACCTTCA & $146 \mathrm{pb}$ & 18 & 59 & AI770197 \\
\hline GADPH - R & Glyceraldehyde-3-phosphate-deshydrogenase & GTGTGCGGTGTCAACATGGA & & 30 & 55 & \\
\hline
\end{tabular}



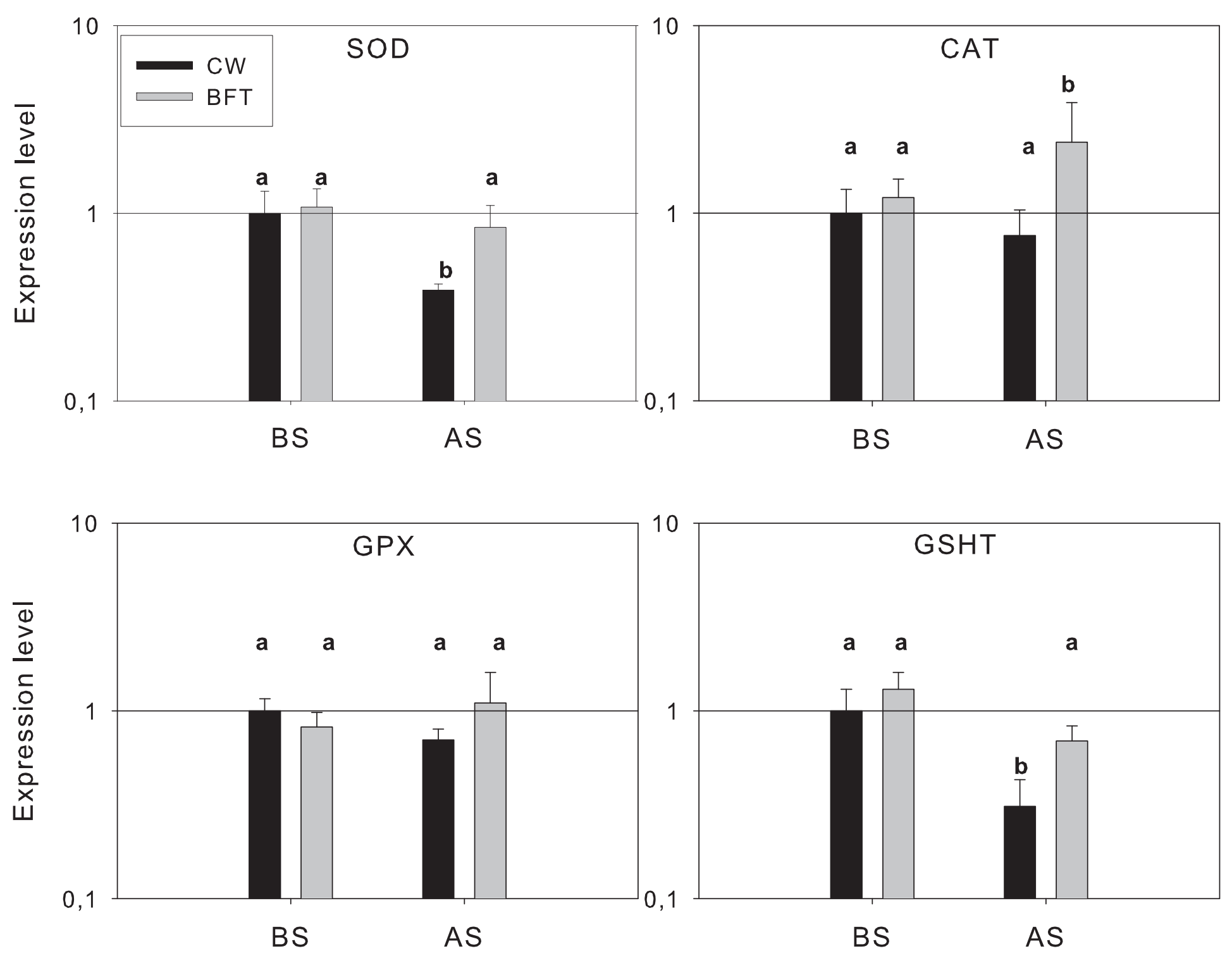

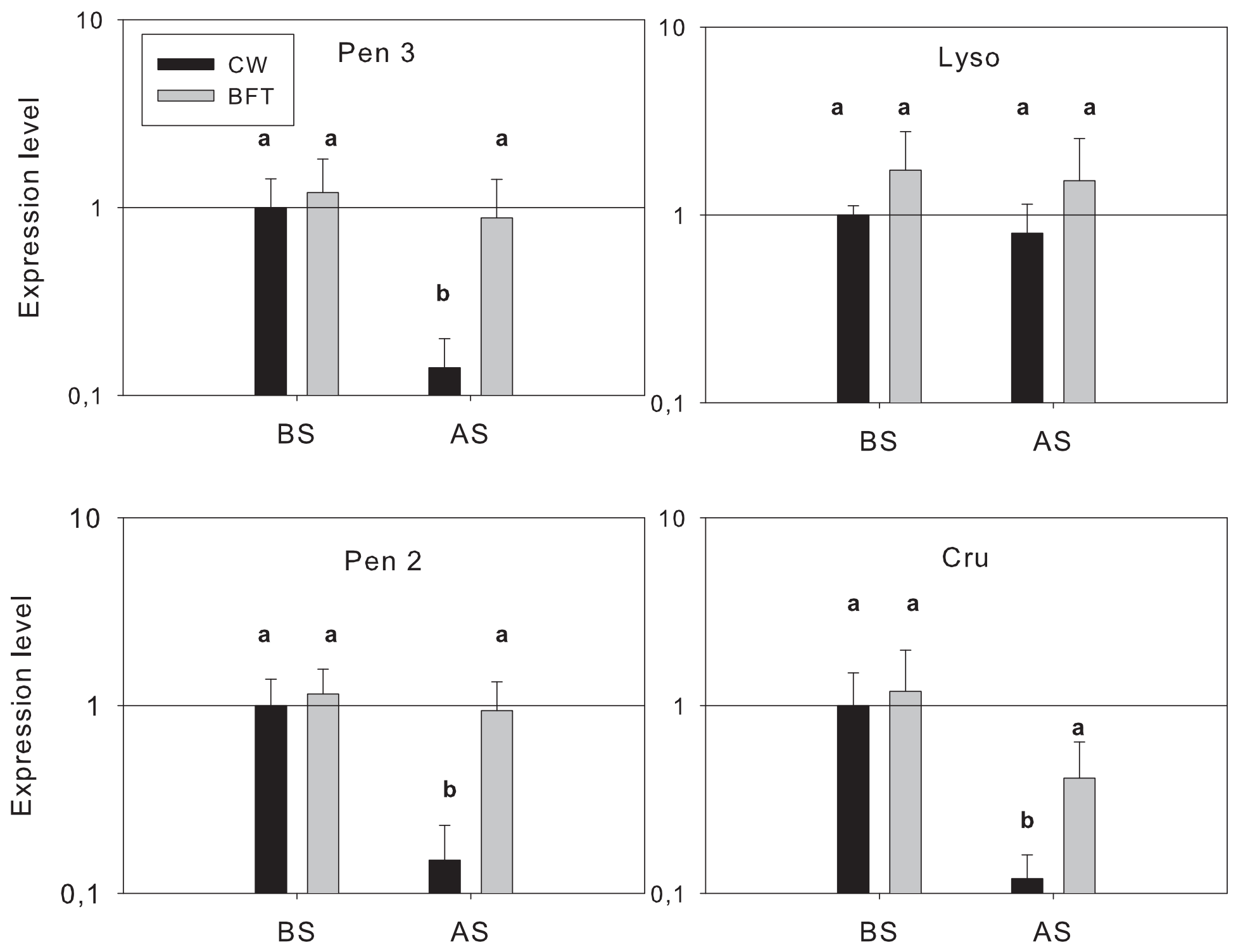


\section{Highlights}

Contrasted rearing conditions, biofloc and clear water, did not affect the expression of genes encoding antioxidant enzymes and antimicrobial peptides.

> Biofloc shrimps maintained antioxidant and antimicrobial peptide responses after $\mathrm{H}_{2} \mathrm{O}_{2}$ stress while the immune competence of clear water shrimp seemed to decrease after stress.

$>$ Biofloc seems to improve the immune resistance of animals against stress. 